Discussion Paper No. 08-025

\title{
Monetary Policy Implementation and the Federal Funds Rate
}

Dieter Nautz and Sandra Schmidt

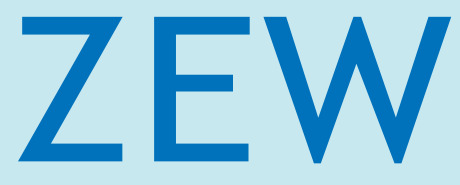

Zentrum für Europäische Wirtschaftsforschung $\mathrm{GmbH}$

Centre for European

Economic Research 
Discussion Paper No. 08-025

\title{
Monetary Policy Implementation and the Federal Funds Rate
}

\author{
Dieter Nautz and Sandra Schmidt
}

Download this ZEW Discussion Paper from our ftp server:

ftp://ftp.zew.de/pub/zew-docs/dp/dp08025.pdf

Die Discussion Papers dienen einer möglichst schnellen Verbreitung von neueren Forschungsarbeiten des ZEW. Die Beiträge liegen in alleiniger Verantwortung der Autoren und stellen nicht notwendigerweise die Meinung des ZEW dar.

Discussion Papers are intended to make results of ZEW research promptly available to other economists in order to encourage discussion and suggestions for revisions. The authors are solely responsible for the contents which do not necessarily represent the opinion of the ZEW. 


\section{Non-Technical Summary}

For many central banks, overnight money markets are the key channel through which monetary policy is executed. Overnight rates, such as the US federal funds rate, are the operational targets of monetary policy that signal the policy-intended interest rate level. Since the 1980s, many central banks, including the Federal Reserve (Fed), have redesigned their monetary policy instruments to ensure that the overnight rate closely follows the central bank's key policy rate and that its volatility remains well contained.

This paper investigates how changes in the Fed's implementation of monetary policy have influenced the dynamics and the volatility of the federal funds rate. Since the early 1980s, the most important changes in the Fed's conduct of monetary policy have referred to the transparency and communication of the federal funds rate target and the working of the reserve requirement system. As a consequence, our empirical analysis focuses on the role of different regimes of interest rate targeting and on the effect of required reserves on the behavior of the federal funds rate.

We find that the Fed's steps towards a more transparent interest rate targeting have improved the Fed's control of the federal funds rate. In particular, the immediate release of monetary policy decisions introduced in February 1994 significantly accelerated the adjustment of the federal funds rate to the policy target rate. The introduction of the balance of risks assessment into the monetary policy statements in January 2000 improved the communication of the Fed concerning the future interest rate path. In fact, we find that this recent step towards more transparency further contributed to stabilize the federal funds rate.

By contrast, the declining trend in required reserves has increased interest rate volatility in the U.S. Paying interest on reserves as it is planned from 2011 onwards shall broaden the reserve base and consequently increase reserve requirements. As a consequence, our empirical findings suggest that the planned introduction of remunerated reserves will decrease the volatility of the federal funds rate in a significant way. 


\section{Zusammenfassung}

Für viele Zentralbanken ist der Interbankenmarkt für Tagesgeld der entscheidende Ausgangspunkt für die Implementierung der geldpolitischen Entscheidungen. Zinssätze für Tagesgeld, wie die Federal Funds Rate in den Vereinigten Staaten, sind das operationale Ziel der Geldpolitik, die das von der Zentralbank gewählte Zinsziel signalisieren. Seit den 80-er Jahren haben viele Zentralbanken einschließlich der Federal Reserve (Fed) ihre geldpolitischen Instrumente umgestaltet, um sicherzustellen, dass der Zinssatz für Tagesgeld sich nahe dem Leitzinssatz bewegt und sich seine Volatilität in engen Grenzen hält.

Die vorliegende Arbeit untersucht, wie sich Veränderungen in der Geldpolitik der Fed auf die Dynamik und die Volatilität der Federal Funds Rate ausgewirkt haben. Die wichtigsten Änderungen seit Beginn der 80-er Jahre haben sich auf die Kommunikation des Leitzinsatzes und auf die Ausgestaltung des Reservehaltungssystems der Banken bezogen. Daher setzt die vorliegende empirische Analyse bei den Fragen an, welche Bedeutung die verschiedenen Kommunikationsmodalitäten auf die Federal Funds Rate haben und wie die Mindestreserven auf das Verhalten der Zinsen wirken.

Die erzielten Ergebnisse zeigen, dass die Schritte der Fed zu stärkerer Transparenz bei den Leitzinsentscheidungen die Kontrolle der Fed über die Federal Funds Rate verbessert haben. Insbesondere die sofortige Veröffentlichung der geldpolitischen Entscheidungen, die im Februar 1994 eingeführt wurde, hat die Anpassung der Federal Funds Rate an den Leitzinssatz beschleunigt. Die Aufnahme eines Risikoausblicks in die Zinsentscheidung im Januar 2000 verbesserte die Kommunikation der Fed hinsichtlich des künftigen Zinspfades. Dieser Schritt hat den Ergebnissen zufolge deutlich dazu beigetragen, die Federal Funds Rate zu stabilisieren.

Im Gegensatz dazu hat der abnehmende Trend der Mindestreserven die Zinsvolatilität in den Vereinigten Staaten erhöht. Es ist zu erwarten, dass die Zinszahlungen auf Reserven, wie sie von der Fed für den Zeitraum ab 2011 vorgesehen werden, die Reservebasis erweitern und folglich auch die Mindestreserven erhöhen. Daher legen die gewonnenen Ergebnisse nahe, dass die geplante Einführung der verzinsten Reservehaltung die Volatilität der Federal Funds rate signifikant vermindern wird. 


\title{
Monetary Policy Implementation and the Federal Funds Rate
}

\author{
Dieter Nautz \\ Goethe University Frankfurt
}

\author{
Sandra Schmidt* \\ Centre for European \\ Economic Research
}

April 16, 2008

\begin{abstract}
This paper investigates how the implementation of monetary policy affects the dynamics and the volatility of the federal funds rate. Since the early 1980s, the most important changes in the Fed's conduct of monetary policy refer to the role of the federal funds rate target and the reserve requirement system. We show that the improved communication and transparency regarding the federal funds rate target has significantly increased the Fed's influence on the federal funds rate since 1994. By contrast, the declining role of required reserves in the U.S. has contributed to higher federal funds rate volatility. Our results suggest that the planned introduction of remunerated reserves will further enhance the controllability of the federal funds rate.
\end{abstract}

Keywords: Dynamics and Volatility of the Federal Funds Rate, Monetary Policy Implementation, Central Bank Communication, Reserve Requirements

JEL classification: E43, E52, C22

${ }^{*}$ We thank Jan Scheithauer for helpful comments and suggestions. Financial support by the Deutsche Forschungsgemeinschaft (DFG) through NA-385/4-1 is gratefully acknowledged. E-mail: nautz@wiwi.unifrankfurt.de, s.schmidt@zew.de 


\section{Introduction}

For many central banks, overnight money markets are the key channel through which monetary policy is executed. Overnight rates, such as the US federal funds rate, are the operational targets of monetary policy that signal the policy-intended interest rate level. Since the 1980s, many central banks, including the Federal Reserve (Fed), have redesigned their monetary policy instruments to ensure that the overnight rate closely follows the central bank's key policy rate and that its volatility remains well contained. ${ }^{1}$ The current paper examines how major developments in the monetary framework of the Fed have influenced the dynamics and the volatility of the federal funds rate.

For the U.S. the most obvious changes in monetary policy implementation refer to the increasing role of the federal funds rate target. Before February 1994, the Fed's interest target rate was more or less implicit and had to be inferred by the public from the Fed's open market operations; see Thornton (2006). Since then, changes in the federal funds target rate have been announced and explained immediately after the Fed's interest rate decision. The introduction of a balance of risk statement in 2000 might have further improved the communication and transparency of monetary policy, see Ehrmann and Fratzscher (2007). During the 1990s sweep account programs could have significantly undermined the reserve base in the U.S. and thus the ability of required reserves to act as an interest rate smoothing liquidity buffer, see e.g. Woodford (2000). With a view to the planned introduction of remunerated reserves in 2011, our second focus is, therefore, on the role of required reserves for the volatility of the federal funds rate.

Our paper is related to the growing literature on the volatility and the dynamics of overnight interest rates. Following the seminal paper by Hamilton (1996), recent examples include Bartolini and Prati (2006) and Pérez Quirós and Rodríguez Mendizábal (2006). Both contributions show that the central bank's operational framework influences the behavior of overnight rates. They do not, however, consider the effects of changes in the role of the central bank's interest rate target, the central bank's communication policy, or the level of required reserves. ${ }^{2}$

In line with the empirical literature, we adopt the EGARCH-framework to model the mean and the time-varying volatility of the daily federal funds rate. In order to capture probably important long-run equilibrium relations governing the federal funds rate dynamics, we specify the mean equation of the EGARCH model as an error correction equation where

\footnotetext{
${ }^{1}$ See Bindseil and Nyborg (2007) for a recent overview of central banks' monetary implementation.

${ }^{2}$ A notable exception is Colarossi and Zaghini (2007) who argue that the improved communication of the Fed ameliorated the transmission of overnight rate volatility to longer term interest rates.
} 
the federal funds rate adjusts to two interest rate spreads. First, in accordance with the expectations theory of the term structure, the federal funds rate $(i)$ may respond to the term spread, defined as the spread between the three month Treasury bill rate and the federal funds rate $(i 3-i)$. Ignoring the presence of a federal funds rate target, Sarno and Thornton (2003) find a significant but asymmetric response of the federal funds rate to the term spread. Yet, given the importance of the federal funds rate target $\left(i^{*}\right)$ for the implementation of monetary policy in the U.S., the response of the federal funds rate to deviations from its target should not be neglected. Following models of the European overnight rate suggested by Benito, León, and Nave (2007) and Nautz and Offermanns (2007), we additionally account for the policy spread $\left(i-i^{*}\right)$ as a second error-correction term governing federal funds rate dynamics. The focus of the current paper is, however, on the relation between monetary policy implementation and the federal funds rate. In particular, we test whether the adjustment of the federal funds rate to deviations from its target depends on the importance and transparency of the federal funds rate target.

Changes in monetary policy implementation may also affect the volatility of the federal funds rate. In particular, preliminary evidence provided by Bennett and Hilton (1997), Wrase (1998), and Hilton (2005) suggests that high reserve requirements stabilize the federal funds rate. In order to test whether required reserves contribute to lower interest rate volatility, we include a normalized measure of required reserves in the volatility equation of the federal funds rate.

Our results clearly indicate that improved communication and transparency of monetary policy decisions significantly enforce the adjustment of the federal funds rate to its target. Therefore, a well-communicated implementation of monetary policy enhances the Fed's control over the federal funds rate. In the same vein, results from the volatility equation show that the introduction of the balance of risks assessment in 2000 has further contributed to stabilizing the federal funds rate. By contrast, the declining trend in required reserves has increased the interest rate volatility in the U.S.

The remainder of the paper is structured as follows. Section 2 introduces the interest rate data and reviews the increasing role of the federal funds rate target in U.S. monetary policy implementation. Section 3 describes the development of required reserves and their possible impact on the volatility of the federal funds rate. Section 4 presents the empirical model designed to test the implications derived in Sections 2 and 3 regarding the effects of monetary policy implementation on the dynamics and the volatility of the federal funds rate. Section 5 summarizes our main results and provides some concluding remarks. 


\section{The increasing importance of the federal funds target rate in the implementation of monetary policy}

\subsection{The communication of the federal funds target rate}

During the 1980s the Fed increasingly made use of an interest rate target in the formulation of its monetary policy decisions. In the corresponding literature, there is some ambiguity as to the exact date when the Fed began targeting the federal funds rate. Hamilton and Jorda (2002) date the beginning of the explicit interest rate targeting at the end of the 1980s. Thornton (2006) interprets the FOMC verbatim transcripts and concludes that the Fed has already targeted the federal funds rate from 1982 onwards. Following Hamilton (1996), our sample period starts in March 1984. This allows us to consistently base the empirical analysis on a time period with a reserve maintenance period length of two weeks. The increasing importance of the federal funds target rate is reflected in the disclosure practice of the Fed. Until January 1994, the target rate was rather implicit and had to be inferred from the open market operations. In fact, FOMC decisions on target rate changes were released only after the subsequent FOMC meeting. In February 1994 a second period of communication policy began with the announcement of monetary policy decisions immediately after an FOMC meeting. A further extension in the communication of interest rate decisions in January 2000 marked the beginning of a third regime of the Fed's communication policy. Since then, FOMC statements have regularly contained a forward-looking component. The so-called balance of risks assessment gives an evaluation if the Fed sees the risks for the economy to be biased towards an economic slowdown (easing bias), towards higher inflationary pressure (tightening bias) or if both risks are supposed to be balanced (neutral assessment). Despite the fact that the statement is not meant to give a binding direction for the immediate next step of monetary policy, the market uses it to form expectations about the near future, see Rasche and Thornton (2002). According to Ehrmann and Fratzscher (2007), the publication of the forward-looking component in the FOMC statement has significantly contributed to a better anticipation of interest rate decisions. ${ }^{3}$

We account for the implications of the three regimes of monetary policy communication on the dynamics and volatility of the federal funds rate as follows. First, we test whether the adjustment of the federal funds rate to the target rate changes with the new disclosure policy, i.e. we allow for different adjustment dynamics of the federal funds rate before and after February 1994. If the immediate publication of the target rate eased the perception of

\footnotetext{
${ }^{3}$ The role of the Fed's communication for the stability of market interest rates has been emphasized by e.g. Kuttner (2001) and Lee (2006).
} 
the monetary policy stance by the market, the adjustment of the federal funds rate to the target rate should have accelerated. Moreover, changes in the communication policy may have influenced the reversion of the federal funds rate to the term spread. In particular, if the outlook for monetary policy facilitated the formation of interest rate expectations since 2000, Treasury bill rates might have become a clearer focal point for market expectations about future federal funds rates. As a result of the Fed's improved communication concerning the future interest rate path, the reaction of the federal funds rate to the term spread might have become stronger.

Besides these communication regimes, we control for further factors related to monetary policy decisions that might influence the federal funds rate. In this regard, a variable of interest is suggested by Ehrmann and Fratzscher (2007). They find that the response of short term interest rates to surprising interest rate decisions depends on whether the FOMC outlook contains a bias (easing or tightening bias, i.e. asymmetric assessment) or not (neutral assessment). The following paragraph provides some information about the history of the bias variable we use in the estimation.

From 1984 to April 1999, FOMC policy directives included a bias to indicate the stance of monetary policy until the next FOMC meeting (intermeeting period). The purpose of this bias was only aimed at an internal use at the Fed, and not at a public one. According to Lapp and Pearce (2000), it was largely consistent with subsequent intermeeting changes in the federal funds rate and target rate decisions. The period from May to December 1999 seemed to prepare the introduction of the balance of risks assessment in January 2000. During this time, the Fed published an outlook about the future direction of monetary policy, but only in case it had changed the monetary policy stance significantly, see Ehrmann and Fratzscher (2007), Poole and Rasche (2003), and Rasche and Thornton (2002). According to Thornton and Wheelock (2000), the practice from May to December 1999 led to considerable speculation among market participants about the interpretation of the statements. Since 2000 , the introduction of the regularly published balance of risks assessment has resolved this uncertainty.

The volatility equation of the federal funds rate estimated in Section 4 will account for the additional information included in the bias of the FOMC statements. In particular, we test whether volatility was higher when monetary policy decisions were accompanied by a bias relative to a neutral assessment. This might have been the case if, for example after 2000, the market was more agitated in expectation of an interest rate change as compared to an expected constant interest rate. Furthermore, following e.g. Hilton (2005), low values of the target rate limit the downward potential of the federal funds rate, implying a relation 
between level and volatility of the federal funds rate. In the following, we will therefore also test whether high interest rate levels tend to coincide with high interest rate volatility.

Table 1: Monetary policy communication and the federal funds rate

\begin{tabular}{lccc}
\hline \hline & $\begin{array}{c}\text { Adjustment to } \\
\text { policy spread }\end{array}$ & $\begin{array}{c}\text { Adjustment to } \\
\text { term spread }\end{array}$ & $\begin{array}{c}\text { Federal funds } \\
\text { rate volatility }\end{array}$ \\
\hline Explicit interest rate target & stronger & & - \\
Balance-of-risks assessment & & stronger & - \\
Interest rate level & & & + \\
FOMC bias & & & + \\
FOMC meeting days & & & + \\
\hline \hline
\end{tabular}

Notes: The table summarizes how distinguishing features of the communication of the central bank's interest rate target are expected to affect the adjustment and the volatility of the federal funds rate. $+[-]$ indicates higher [lower] fed funds rate volatility.

\subsection{Interest rate spreads and monetary policy communication regimes}

A first look at the policy spread suggests that the Fed's steps towards more transparency have rendered monetary policy implementation more effective. Apparently, the policy spread $\left(i-i^{*}\right)$ has gradually tightened and become less volatile since the early 1980s, see Figure 1. Table 2 shows some descriptive interest rates statistics for the three different regimes of monetary policy communication that confirm this view. In particular, both mean and standard deviation of the policy spread have decreased remarkably from 1984 until 2007. Note that the introduction of the balance of risks assessments in 2000 had no notable impact on the mean of the policy spread. In contrast, the improved communication regarding the future monetary policy stance may have strongly reduced the volatility of the policy spread.

The manner in which monetary policy is implemented may also affect the behavior of the term spread $(i 3-i)$, compare Figure 2 . Note that the spread is negative throughout the sample period which stems from the exemption of three-month Treasury bills from some local and state taxes, see Sarno and Thornton (2003). Similar to the policy spread, the term spread has tightened and its standard deviation has decreased over the sample period. 
Figure 1: Federal funds rate, federal funds rate target, and the policy spread

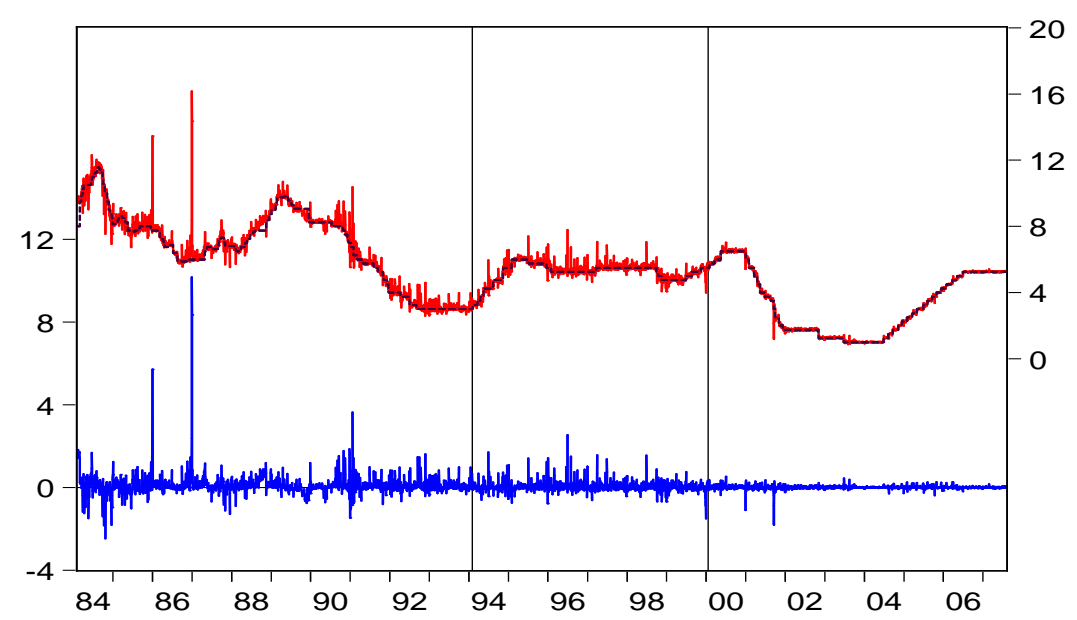

Notes: Right scale: Effective federal funds rate $(i)$, the federal funds rate target $\left(i^{*}\right.$, dashed line). Left scale: policy spread $\left(i-i^{*}\right)$. The vertical lines indicate the various regimes of monetary policy communication.

Figure 2: Federal funds rate, Treasury bill rate, and the term spread

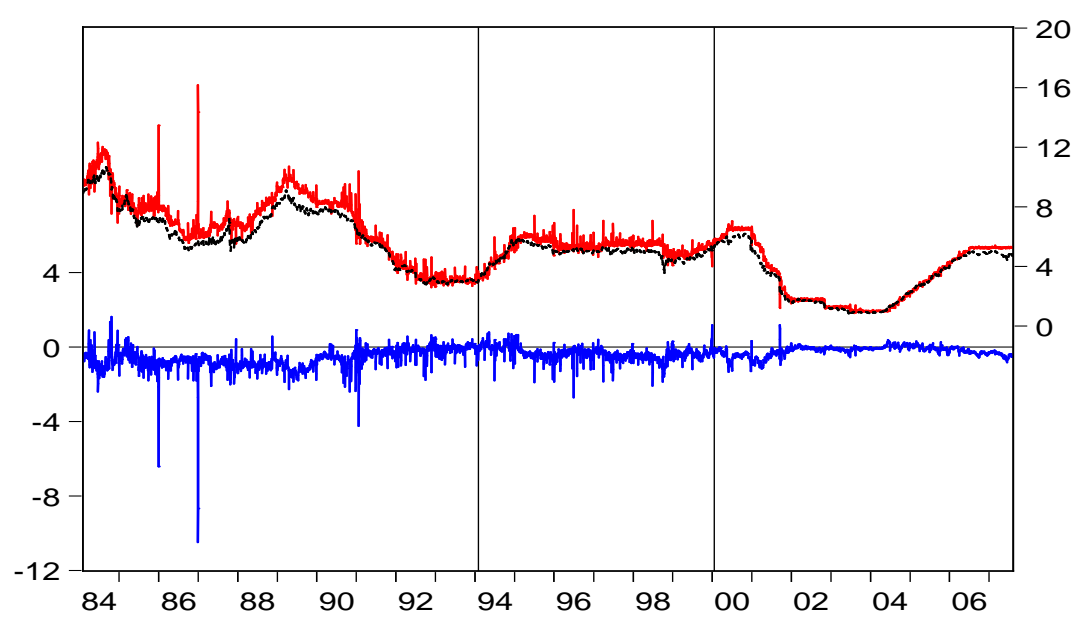

Notes: Right scale: Effective federal funds rate $(i)$, Treasury bill rate ( $i 3$, dashed line). Left scale: term spread $(i 3-i)$. The vertical lines indicate the various regimes of monetary policy communication. 
Table 2: Interest rate statistics and regimes of monetary policy communication

\begin{tabular}{lllll}
\hline \hline & Federal funds rate & Policy spread & Treasury bill rate & Term spread \\
\hline \hline Mar 1984 - Jan 1994 & & & & \\
\hline Mean & 6.85 & 0.09 & 6.23 & -0.63 \\
Median & 7.11 & 0.04 & 6.25 & -0.63 \\
Standard deviation & 2.30 & 0.48 & 2.00 & 0.58 \\
\hline Feb 1994 - Jan 2000 & & & & -0.34 \\
\hline Mean & 5.24 & 0.02 & 4.90 & -0.35 \\
Median & 5.38 & -0.01 & 5.00 & 0.34 \\
Standard deviation & 0.61 & 0.23 & 0.49 & -0.22 \\
\hline Jan 2000 - Aug 2007 & & & 3.14 & -0.14 \\
\hline Mean & 3.36 & 0.01 & 3.00 & 0.26 \\
Median & 3.13 & 0.00 & 1.75 & \\
Standard deviation & 1.91 & 0.10 & & \\
\hline \hline
\end{tabular}

Notes: All statistics are derived from daily data. The effective federal funds rate is the overnight interbank rate for federal funds (reserves).

\section{The declining role of reserve requirements in the imple- mentation of monetary policy}

\subsection{Reserve requirements and interest rate volatility}

In contrast to the reserve requirement systems of the European Central Bank and the Bank of England, reserve balances are not remunerated in the United States. As a consequence, they represent a cost for depository institutions implying that banks aim at operating at reserve levels as low as possible. Under the prevailing average reserve requirement system, reservable funds are perfect substitutes from one day to the other. Operating at minimum reserves may make it more difficult for banks to absorb liquidity shocks and may thereby translate into a higher volatility of the federal funds rate. To increase the efficiency of its reserve requirement system, the Fed recently decided to pay interest on reserves from October 2011 onwards.

Following Wrase (1998), reserve requirements can affect the volatility of the federal funds rate primarily in two ways. First, on the demand side, banks use their accounts at the Fed not only to hold reserves but also to settle payments with other banks. However, if banks minimize their reserve holdings by using e.g. sweep account programs, reserves might be reduced below the amount necessary to settle payments. ${ }^{4}$ As a consequence, liquidity shocks can lead to large swings in the federal funds rate. Second, on the supply side,

\footnotetext{
${ }^{4}$ By the sweep account practice, banks shift deposits subject to reserve requirements into a deposit class without reserve requirements.
} 
reduced reserve holdings hamper the Fed's liquidity management, because banks' demand for reserves to settle payments varies more than their demand to meet reserve requirements. Consequently, higher reserve holdings should represent a liquidity buffer which facilitates both banks' reserve management and the Fed's supply of reserves. Accordingly, higher reserves should contribute to a lower volatility of the federal funds rate. ${ }^{5}$

Figure 3 shows that the level of required reserves has varied considerably since 1984. What is particularly striking is that it declined sharply since about 1990, when the Fed eliminated required reserves on non-transaction deposits. A second remarkable decline followed in April 1992 when the Fed lowered the reserve ratio on transaction deposits from 12 to 10 percent. With the rapid expansion of sweep account programs in 1995, reserve requirements fell steadily until the opportunities to extend sweep accounts were largely exhausted in 1999. Figure 4 depicts reserve requirements normalized by total deposits, i.e. by the sum of transaction and non-transaction deposits, in order to account for the upward trend of total deposits, see Figure 5 in the Appendix. Normalizing reserve requirements by total deposits captures both the decline in reserve requirements due to the exemption of non-transaction deposits from the reserve base, and the distorting effect of sweep account programs, which could not be achieved by normalizing by transaction deposits only, see Brunner and Lown (1993). ${ }^{6}$

According to O'Brien (2007), interest rate smoothing can nowadays be seen as the main reason for imposing reserve requirements. ${ }^{7}$ Yet, the available evidence on the impact of required reserves on the dynamics and volatility of the federal funds rate is surprisingly mixed and elusive. A descriptive analysis from Wrase (1998) indicates that intraday volatility of the federal funds rate strongly increased during the first months after the exemption of non-transaction deposits of the reserve base and slightly increased with the sweep account programs since 1995. Bennett and Hilton (1997) report similar findings for the sweep account practice. Empirical results obtained by Brunner and Lown (1993) suggest that there

\footnotetext{
${ }^{5}$ Note that the interest rate smoothing effect of required reserves can be seen as debatable. For example, the model by VanHoose and Humphrey (2001) produces ambiguous theoretical predictions on the effect of reserves on interest rate volatility. In particular, their model predicts an effect in the opposite direction, which results from banks applying a larger share of reserves to cover unexpected payment shocks in case required reserves decrease in levels.

${ }^{6}$ Previous studies often considered the level of reserve requirements, see Bennett and Hilton (1997), VanHoose and Humphrey (2001), and Hilton (2005). In the context of testing for a liquidity effect in the federal funds market, Carpenter and Demiralp (2008) emphasize the importance to differentiate between required reserves and required reserve balances banks hold at the Fed. Required reserves can be met either by vault cash or by balances at the Fed (required reserve balances). In our analysis, this distinction does not affect the main results, see Figure 6 and subsection A.2 in the Appendix.

${ }^{7}$ A proposition to achieve low overnight rate volatility without required reserves comes from Holthausen, Monnet, and Würtz (2007). In their model, the liquidity buffer function of required reserves is taken over by a central bank lending facility from which banks can borrow overnight money at presumably the central bank target rate up to a limited amount. Their model produces a lower interest rate volatility compared to a system with average reserve accounting, which is also due to non-existing end-of-period effects.
} 
is a negative, albeit small, influence of reserve requirements divided by transaction deposits on the volatility of the federal funds rate. Finally, Ayuso, Haldane, and Restoy (1997) provide indirect evidence in favor of the hypothesis that reserve requirements stabilize interest rate volatility. They observe that countries with higher reserve requirements tend to have a lower volatility of short-term interest rates. In order to shed more light on this issue, our empirical model for the federal funds rate enables us to test whether reserve requirements on total deposits actually lower the volatility of the federal funds rate.

Figure 3: Required reserves

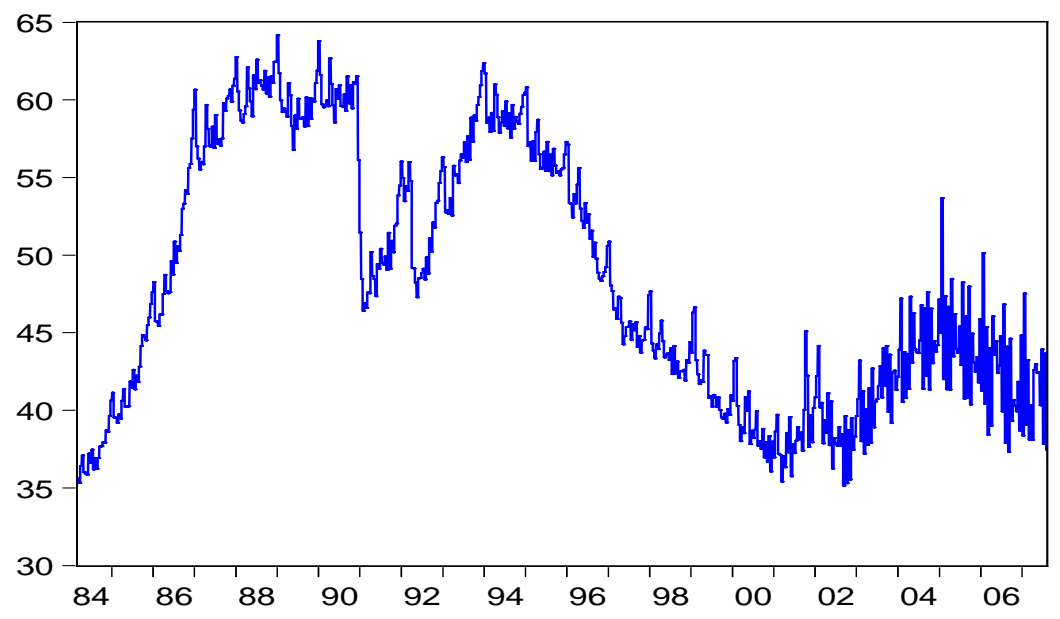

Notes: Required reserves in bn USD, non-seasonally adjusted, not adjusted for breaks due to institutional changes in the reserve requirement framework.

Figure 4: Required reserves on total deposits

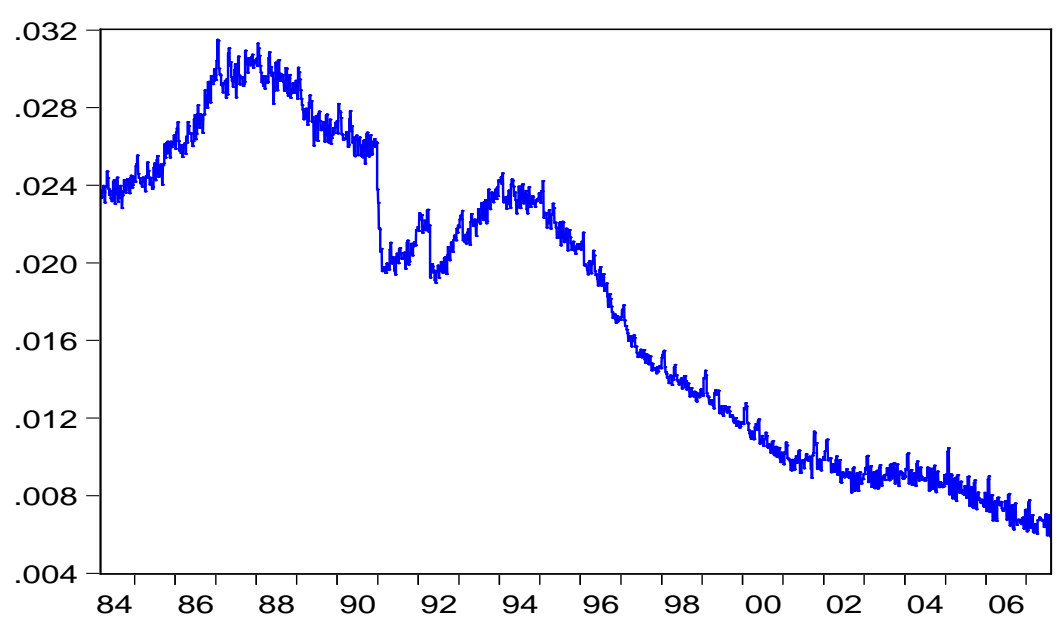

Notes: Required reserves divided by total deposits. 


\subsection{Reserve accounting rules and interest rate volatility}

This section discusses how the prevailing features and undertaken changes of the reserve requirement system are supposed to influence the volatility of the federal funds rate.

Average reserve accounting In a system of average fulfilment of reserve requirements, rational banks should arbitrage away any predictable pattern of the federal funds rate during a maintenance period. As a consequence, the federal funds rate should follow a martingale process. However, Hamilton (1996) found predictable patterns of the federal funds rate during the maintenance period. For example, the federal funds rate tends to move downwards on Friday and increase again on Monday. Moreover, the federal funds rate is typically higher on the last day of the maintenance period, reflecting the so-called Settlement Wednesday tightness. This effect may have changed since August 1998, when the Fed began to supply more liquidity during the last days of a maintenance period. The violation of the martingale hypothesis has been confirmed by many other authors, see e.g. Prati, Bartolini, and Bertola (2003). In particular, there is consensus about an increased volatility and tightness on Settlement Wednesdays, see Furfine (2000). Our estimation therefore controls for day-specific effects within a maintenance period.

Contemporaneous versus lagged reserve computation Our empirical analysis of the federal funds rate behavior shall account for further institutional details of the reserve accounting practice that might influence the volatility of the federal funds rate. In 1998, in particular, the Fed switched from contemporaneous to lagged reserve computation in order to facilitate banks' reserve management and to reduce the volatility of the federal funds rate. Under contemporaneous reserve computation banks only knew their definite level of reserve requirements on the penultimate day of the maintenance period, see e.g. Gilbert and Trebing (1982). The higher uncertainty under the contemporaneous accounting system may well translate into a more erratic level of reserve holdings and thus a higher variation of the federal funds rate compared to the system of a lagged accounting practice, see Lasser (1992) and Lee (2002). Since banks know the required reserves in advance of a maintenance period, the introduction of lagged reserve requirements in July 1998 should have mitigated the volatility of the federal funds rate. 
Discount window Finally, the volatility of the federal funds rate might have been influenced by the new operation procedures for the utilization of the discount window introduced in January 2003. These new procedures were supposed to facilitate and encourage banks' borrowing from the Fed of short-term funds. Although banks hardly made use of this possibility, the mere knowledge of its presence may have contributed to a stabilization of the federal funds rate, see Furfine $(2003,2005)$. Table 3 summarizes the predictions regarding the relation between reserve variables and the volatility of the federal funds rate.

Table 3: Reserve variables and the federal funds rate

\begin{tabular}{lc}
\hline \hline & $\begin{array}{c}\text { Federal funds } \\
\text { rate volatility }\end{array}$ \\
\hline Required reserves on total deposits & - \\
Lagged computation & - \\
Discount window & - \\
Settlement Wednesday & + \\
\hline \hline
\end{tabular}

Notes: The table summarizes how required reserves and distinguishing features of the Fed's reserve requirement framework are expected to affect the volatility of the federal funds rate. + [-] indicates higher [lower] fed funds rate volatility. 


\section{An empirical model of the federal funds rate}

\subsection{The econometric specification}

In this section we present and estimate the empirical model designed for testing the empirical relevance of the implications of the Fed's monetary policy implementation on the federal funds rate. Following the empirical literature, the dynamics and volatility of the federal funds rate are modeled in an EGARCH framework where equations explaining the conditional mean and the conditional variance are estimated simultaneously via Maximum Likelihood. Equation (1) presents the specification of the mean equation of the federal funds rate.

$$
\begin{aligned}
\Delta i_{t} & =\delta_{1} D_{t}^{I}+\delta_{2} D_{t}^{I I}+\delta_{3} D_{t}^{I I I} \\
& +\alpha_{1} D_{t}^{I}\left(i-i^{*}\right)_{t-1}+\alpha_{2}\left(1-D_{t}^{I}\right)\left(i-i^{*}\right)_{t-1} \\
& +\beta_{1}\left(1-D_{t}^{I I}\right)(i 3-i)_{t-1}+\beta_{2} D_{t}^{I I I}(i 3-i)_{t-1} \\
& +\phi_{1} \Delta i_{t}^{*}+\sum_{l=1}^{5} \phi_{2, l} \Delta i_{t-l}+\sum_{m=1}^{5} \phi_{3, m} \Delta i 3_{t-m}+\theta^{\prime} X_{1 t}+\sigma_{t} \varepsilon_{t}
\end{aligned}
$$

In order to account for the economic long-run relations governing the federal funds rate, the mean equation is specified as error-correction equation, see e.g. Benito, León, and Nave (2007) and Nautz and Offermanns (2007). The federal funds rate (i) adjusts to deviations from its target, i.e. the policy spread $\left(i-i^{*}\right)$, and, in line with the expectations theory of the term structure, to the term spread $(i 3-i)$. However, following the theoretical predictions summarized in Table 1, the response of the federal funds rate to both interest rate spreads may depend on the prevailing monetary policy implementation regime. Specifically, let $D^{I}$ be the dummy variable associated with the first sample period (1984 to 1994) when the federal funds rate target was less transparent and probably only played a minor role. Due to the increased emphasis on the federal funds rate target in monetary policy implementation, the adjustment coefficient of the policy spread may be different before $\left(D^{I}\right)$ and after $\left(1-D^{I}\right)$ the adoption of a more explicit interest rate targeting.

In the same vein, the improved expectations management of the Fed implied by the release of balance of risks assessments could have influenced the response of the federal funds rate to the term spread. Accordingly, we define $D^{I I I}$ as the dummy variable associated with the third regime of policy communication (2000 to 2007) covering the period related to the Fed's balance of risks assessment. $D^{I I}$ covers the intermediate period from 1994 to 2000 . In line with the interest rate statistics shown in Table 2, we use these dummy variables as regressors to control for regime-dependent mean shifts. Following Hamilton (1996), the 
mean equation (1) of the federal funds rate additionally includes the change of the federal funds rate target, lagged differences of interest rates and dummy variables accounting for calendar effects $\left(X_{1}\right)$.

In line with the predicted impact of monetary policy implementation and federal funds rate volatility (see Tables 1 and 3), the volatility equation (2) accounts for the changes of the Fed's communication policy and the reserve requirement system:

$$
\begin{aligned}
\log \left(\sigma_{t}^{2}\right) & =\omega_{0}+\omega_{1} \log \left(\sigma_{t-1}^{2}\right)+\omega_{2}\left|\frac{\varepsilon_{t-1}}{\sigma_{t-1}}\right|+\omega_{3} \frac{\varepsilon_{t-1}}{\sigma_{t-1}} \\
& +\vartheta_{1} i_{t-1}^{*}+\vartheta_{2} D_{t}^{I I}+\vartheta_{3} D_{t}^{I I I}+\vartheta_{4} D_{t}^{B I A S}+\vartheta_{5} D_{t}^{F O M C} \\
& +\vartheta_{6} r r_{t}+\vartheta_{7} D_{t}^{L R R}+\vartheta_{8} D_{t}^{E O P}+\vartheta_{9} D_{t}^{D W}+\varphi^{\prime} X_{2 t}+\nu_{t} .
\end{aligned}
$$

Specifically, the dummy variables $D^{I I}$ and $D^{I I I}$ capture possible changes in the conditional volatility of the federal funds rate due to the innovations of monetary policy communication. The bias in the FOMC policy directive or, from 2000 onwards, in the balance of risks assessment is considered by the dummy variable $\left(D^{B I A S}\right)$. The corresponding coefficient reveals the effect of the bias on the volatility of the federal funds rate relative to a neutral FOMC assessment. Finally, we control for FOMC meeting days $\left(D^{F O M C}\right)$ and the level of the federal funds rate target, see Table 1.

The second group of variables refers to the reserve requirement system, see Table 3 . For the purpose of estimation, we divide required reserves $(R R)$ by total deposits $(T D)$ to obtain a measure for the relative aggregate reserve position of banks. Reserve requirement data denote the daily average a bank has to hold on every day of a maintenance period. Under contemporaneous reserve requirement computation, we instrument for the required reserves of the current maintenance period by a lag of one period. Total deposits are averages over one week, ending on Wednesday. Using a lag of one week as the closest proxy for current deposits, Equation (3) defines the level of required reserves normalized by total deposits $r r_{t}$.

$$
r r_{t}= \begin{cases}\frac{R R_{t-10}}{T D_{t-5}} & \text { under contemporaneous reserve requirement computation } \\ \frac{R R_{t}}{T D_{t-5}} & \text { under lagged reserve requirement computation. }\end{cases}
$$

Institutional issues related to the reserve requirement system are accounted for by dummies for the introduction of lagged reserve requirements in August $1998\left(D^{L R R}\right)$, Settlement Wednesdays $\left(D^{E O P}\right)$, and the new design of the discount window facility $\left(D^{D W}\right)$ in January 2003. Finally, the usual calendar dummies are summarized in the vector $X_{2}$. For a complete list of variables, see Table 8 in the Appendix. 


\subsection{Empirical results for federal funds rate dynamics and volatility}

We estimated the empirical model of the federal funds rate, (1) and (2), with daily data from 1 March 1984 to 8 August 2007. ${ }^{8}$ Table 4 summarizes the results for both the mean and the volatility equation of the federal funds rate. In the Appendix, we present the complete set of estimated coefficients (Tables 6 and 7) including a discussion of calendar effects and their implications for the martingale hypothesis, see Hamilton (1996).

The response of the federal funds rate to interest rate spreads For both interest rate targeting regimes, the estimated coefficients of the policy spread $\left(\hat{\alpha}_{1}, \hat{\alpha}_{2}\right)$ indicate a highly significant adjustment of the federal funds rate to its target. In line with theoretical predictions, the immediate announcement of interest rate decisions introduced in February 1994 strengthened the adjustment of the market rate to the official rate. Wald tests confirm that the coefficients significantly depend on the Fed's interest targeting regime. Whereas 47 percent $\left(\hat{\alpha}_{1}\right)$ of a target rate deviation is corrected within a day before February 1994, the daily adjustment has risen to 69 percent $\left(\hat{\alpha}_{2}\right)$ since then. In line with Nautz and Scheithauer (2008), the persistence of the U.S. policy spread has significantly decreased since February 1994.

According to the estimation results obtained for the coefficients $\beta_{1}, \beta_{2}$, the federal funds rate adjusts significantly to the term spread. However, the adjustment coefficients appear to be very small. Rather, the federal funds rate target turns out to be the main stabilizing factor for the federal funds rate. In particular, the introduction of the balance of risks assessment did not lead to a stronger adjustment of the federal funds rate to the term spread. Sarno and Thornton (2003) find much larger adjustment coefficients related to the Treasury bill rate. However, their findings might be biased due to the omission of the policy spread. Furthermore, in contrast to Sarno and Thornton (2003), we do not find that the adjustment of the federal funds rate depends on the sign of the term spread. ${ }^{9}$

\footnotetext{
${ }^{8}$ The sample period does not include interest rate data distorted by the recent liquidity crisis. The analysis of the effects of the liquidity crisis on the behavior federal funds rate is left for future research.

${ }^{9}$ Results obtained for asymmetric error-correction equations are not reported but are available upon request. Sarno and Thornton (2003) focus exclusively on the relationship between the Treasury bill and federal funds rate. They estimate a cointegrating vector of $(i, i 3)=(1,-1.15)$, while the expectation hypothesis implies that interest rates of longer and shorter maturities should be cointegrated with $(i, i 3)=$ $(1,-1)$, see Campbell and Shiller (1987). In our sample period, unit root tests show that the term spread can be assumed to be stationary, see Table 5 in the Appendix.
} 
Table 4: Monetary policy implementation and the behavior of the federal funds rate

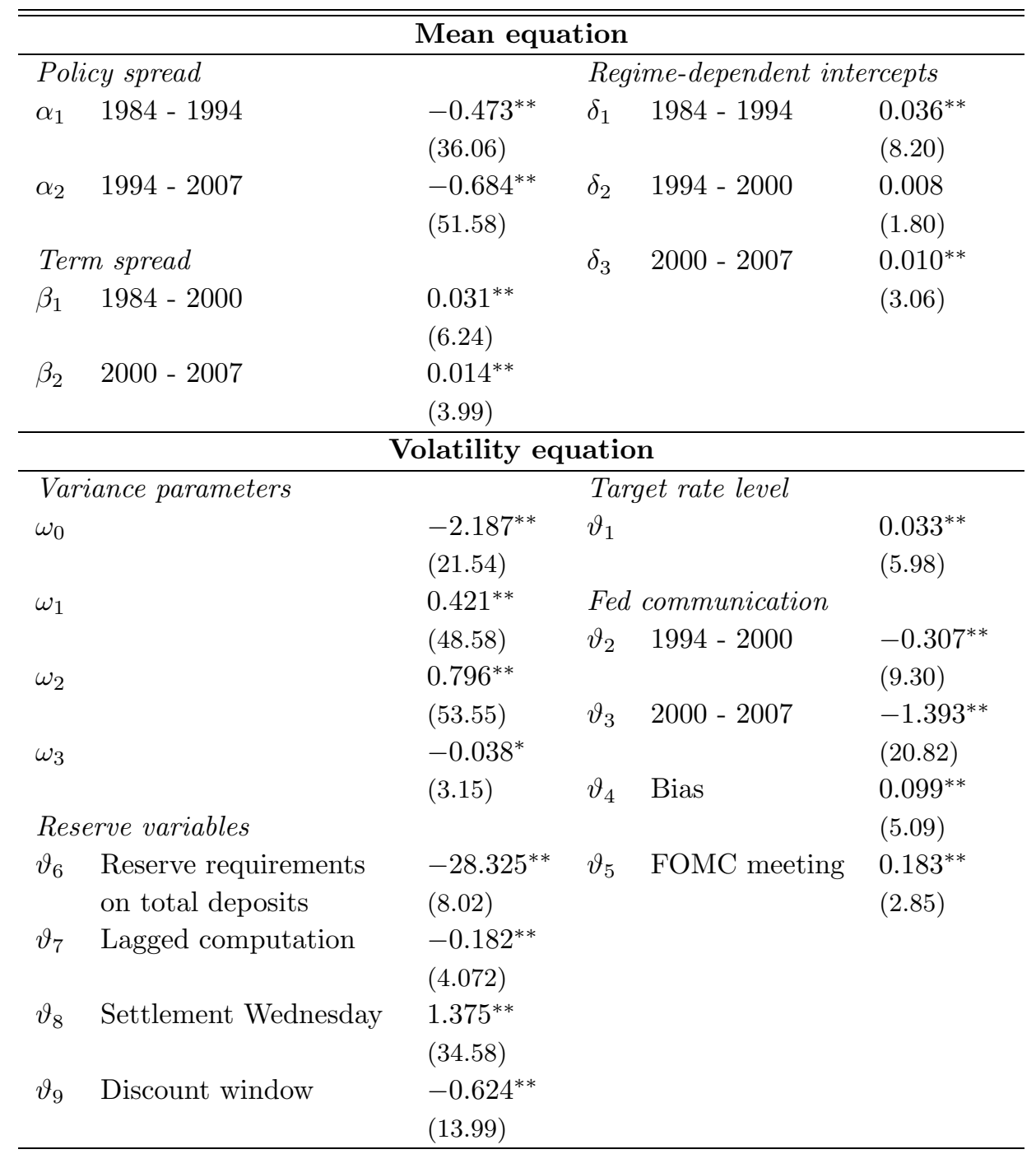

\section{Wald test on parameter equality}

$\mathcal{H}_{0}$ : Same speed of adjustment of the federal funds rate to the

Policy spread pre/post 1994: $\quad \alpha_{1}=\alpha_{2} \quad 0.000$

Term spread pre/post 2000: $\quad \beta_{1}=\beta_{2} \quad 0.001$

Notes: Estimation on basis of daily data. HAC consistent, absolute t-values in parenthesis. ${ }^{* *} /{ }^{*}$ denotes significance at the $1 \%-/ 5 \%$-level. The estimated model is presented in Equations (1) and (2). Wald statistics are presented as p-values. See Tables 6 and 7 in the Appendix for detailed estimation results and Table 8 in the Appendix for a description of variables. 
Interest rate targeting regimes and federal funds rate volatility The lower section of Table 4 summarizes the results obtained for the volatility equation (2) of the federal funds rate. To begin with, the results confirm the presumption of Hilton (2005) that higher target rate levels are accompanied by higher volatility of the market rate: the estimated coefficient $\left(\hat{\vartheta}_{1}=0.033\right)$ is significantly positive. The dummy variables indicating the three communication regimes demonstrate that a higher transparency reduces the interest rate volatility. While the new disclosure practice in $1994\left(\hat{\vartheta}_{2}=-0.307\right)$ only had a slightly negative effect on volatility, a much stronger reduction resulted from the introduction of the balance of risks assessment in January $2000\left(\hat{\vartheta}_{3}=-1.393\right)$. Note that the Fed's bias published in the FOMC policy directive and in the balance of risks assessment also has a significant impact on federal funds rate volatility. Specifically, periods with a bias $\left(\hat{\vartheta}_{4}=0.099\right)$ are accompanied by a higher volatility of the federal funds rate compared to a neutral assessment, see also Ehrmann and Fratzscher (2007). Finally, in line with earlier

findings by Kuttner (2001), the significantly positive coefficient of $D^{F O M C}\left(\hat{\vartheta}_{5}=0.183\right)$ indicates that the market seems to be more active and volatile on FOMC meeting days in comparison to days of the intermeeting period.

\section{The impact of the reserve requirement system on federal funds rate volatility}

Our results strongly support the hypothesis that relatively high reserve requirements stabilize the federal funds rate. In particular, the estimated coefficient of $\operatorname{rr}\left(\hat{\vartheta}_{6}=-28.325\right)$ indicates a significantly negative relationship between required reserves on total deposits and federal funds rate volatility. This implies that sweep account programs, which particulary expanded in the second half of the 1990s, contributed to increasing federal funds rate volatility. However, there is evidence that reforms of the Fed's operational framework helped to stabilize the federal funds rate. For example, the introduction of lagged reserve requirement computation in August 1998 considerably reduced $\left(\hat{\vartheta}_{7}=-0.182\right)$ the uncertainty of banks concerning their reserve requirements and facilitated the reserve management. According to Prati, Bartolini, and Bertola (2003), the lower volatility of the federal funds rate since August 1998 may have been reinforced by the Fed becoming more active in the market. The facilitated access to borrowing from the Fed due to the new design of the discount window $\left(\hat{\vartheta}_{9}=-0.623\right)$ apparently further stabilized the federal funds rate. Following Furfine (2005), the mere presence of the new lending facility may have had a stabilizing effect on the federal funds rate. Finally, the volatility equation confirms the well-known phenomenon of higher overnight rate volatility on the last day of the maintenance period $\left(\hat{\vartheta}_{8}=1.375\right)$ for countries with average reserve requirements, see e.g. Hamilton (1996) for the U.S. or Pérez Quirós and Rodríguez Mendizábal (2006) for Germany and the euro area. 


\section{Conclusions}

This paper has investigated the impact of the Fed's implementation of monetary policy on the dynamics and the volatility of the federal funds rate. Since the early 1980s, the most important changes in the Fed's conduct of monetary policy have referred to the transparency and communication of the federal funds rate target and the working of the reserve requirement system. As a consequence, our empirical analysis has focused (1) on the role of different regimes of interest rate targeting and (2) on the effect of reserve requirements on the behavior of the federal funds rate.

Following the recent literature on the dynamics and volatility of overnight rates, we found that the Fed's steps towards a more transparent interest rate targeting have improved the Fed's control of the federal funds rate. In particular, the immediate release of monetary policy decisions introduced in February 1994 significantly strengthened the link between the federal funds rate and its policy target. The introduction of the balance of risks assessment into the FOMC-statements in January 2000 improved the communication of the Federal Reserve concerning the future interest rate path. In fact, we find that this recent step towards more transparency further contributed to stabilize the federal funds rate.

Our results illustrate that the volatility of the federal funds rate decreases with the level of required reserves (normalized by total deposits). This effect confirms the function of reserve balances at the Fed in order to facilitate the settlement of payments in the interbank market, see e.g. Hilton (2005) and Bennett and Peristiani (2002). The sweep account programs of the mid-1990s in particular have contributed to an increasing volatility of the federal funds rate. The paper might also add to the current discussion following the decision of the Fed to pay interest on reserves from 2011 onwards. ${ }^{10}$ Paying interests on reserves is supposed to broaden the reserve base and should consequently increase reserve requirements. As a consequence, our empirical findings suggest that the planned introduction of remunerated reserves will decrease the volatility of the federal funds rate in a significant way.

\footnotetext{
${ }^{10}$ See e.g. the Fed Policy Update: "Fed to Begin Paying Interest on Reserves", by John Walter and Patricia Wescott, Winter 2007. Paying interest on reserves may have further favorable effects. Following Goodfriend (2002) and Ennis and Weinberg (2007), the Fed can improve its leverage over the market rate by remunerating reserves - also excess reserves - at its chosen interest rate. According to Martin and Monnet (2008), the new system will correct market distortions and improve market efficiency.
} 


\section{References}

Ayuso, J., A. G. Haldane, and F. Restoy (1997): "Volatility Transmission along the Money Market Yield Curve," Weltwirtschaftliches Archiv, 133(1), 56-75.

Bartolini, L., And A. Prati (2006): "Cross-country differences in monetary policy execution and money market rates' volatility," European Economic Review, 50(2), 349-376.

Benito, F., A. León, and J. Nave (2007): "Modeling the Euro Overnight Rate," Journal of Empirical Finance, 14(5), 756-782.

Bennett, P., And S. Hilton (1997): "Falling Reserve Balances and the Federal Reserve," Current Issues in Economics and Finance, Federal Reserve Bank of New York, 3(5).

Bennett, P., and S. Peristiani (2002): "Falling Reserve Balances and the Federal Reserve," Economic Policy Review, Federal Reserve Bank of New York, May, 53-68.

Bindseil, U., And K. G. Nyborg (2007): "Monetary Policy Implementation: A European Perspective," NHH Department of Finance $\&$ Management Science Discussion Paper, No. $2007 / 10$.

Brunner, A. D., And C. S. Lown (1993): "The Effects of Lower Reserve Requirements on Money Market Volatility," The American Economic Review, 83(2), Papers and Proceedings of the Hundred and Fifth Annual Meeting of the American Economic Association, 199-205.

Campbell, J. Y., and R. J. Shiller (1987): "Cointegration and Tests of Present Value Models," The Journal of Political Economy, 95(5), 1062-1088.

Carpenter, S., and S. Demiralp (2008): "The Liquidity Effect in the Federal Funds Market: Evidence at the Monthly Frequency," Journal of Money, Credit and Banking, 40(1), 1-24.

Colarossi, S., and A. Zaghini (2007): "Gradualism, Transparency and Improved Operational Framework: A Look at the Overnight Volatility Transmission," CFS Working Paper, 2007/16.

Ehrmann, M., And M. Fratzscher (2007): "Transparency, Disclosure and the Federal Reserve," International Journal of Central Banking, 3(1), 179-225.

Ennis, H. M., And J. A. Weinberg (2007): "Interest on Reserves and Daylight Credit," Federal Reserve Bank of Richmond Economic Quarterly, 93(2), 111-142. 
Furfine, C. H. (2000): "Interbank Payments and the Daily Federal Funds Rate," Journal of Monetary Economics, 46, 535-553.

(2003): "Standing Facilities and Interbank Borrowing: Evidence from the Federal Reserve's New Discount Window," International Finance, 6(3), 329-347.

(2005): "Discount Window Borrowing: Understanding Recent Experience," Essays on Issues, The Federal Reserve Bank of Chicago, 212.

Gilbert, A. R., and M. E. Trebing (1982): "The New System of Contemporaneous Reserve Requirements," Federal Reserve Bank of St. Louis, December 1982.

Goodfriend, M. (2002): "Interest on Reserves and Monetary Policy," Federal Reserve Bank of New York Economic Policy Review, 8(1), 77-84.

Hamilton, J. D. (1996): "The Daily Market for Federal Funds," The Journal of Political Economy, 104(1), 26-56.

Hamilton, J. D., and O. Jorda (2002): "A Model of the Federal Funds Rate Target," The Journal of Political Economy, 110(5), 1135-1167.

Hilton, S. (2005): "Trends in Federal Funds Rate Volatility," Current Issues in Economics and Finance, Federal Reserve Bank of New York, 11(7), 1-7.

Holthausen, C., C. Monnet, and F. Würtz (2007): "Implementing Monetary Policy With No Reserve," paper presented at the Federal Reserve Bank of New York conference "The Role of Money Markets", http://www.newyorkfed.org/research/conference/ 2008/role_money_mkts.html.

Kuttner, K. N. (2001): "Monetary Policy Surprises and Interest Rates: Evidence from the Fed Funds Futures Market," Journal of Monetary Economics, 47, 523-544.

Lapp, J. S., And D. K. Pearce (2000): "Does a Bias in FOMC Policy Directive Help Predict Intermeeting Policy Changes?," Journal of Money, Credit and Banking, 32(3), Part 1, 435-441.

LAsser, D. J. (1992): "The Effect of Contemporaneous Reserve Accounting on the Market for Federal Funds," Journal of Banking and Finance, 16, 1047-1056.

LeE, J. (2002): "Federal Funds Rate Target Changes and Interest Rate Volatility," Journal of Economics and Business, 54, 159-191.

(2006): "The Impact of Federal Funds Target Changes on Interest Rate Volatility," International Review of Economics and Finance, 15, 241-259. 
Martin, A., And C. Monnet (2008): "Monetary Policy Implementation Frameworks: A Comparative Analysis," Federal Reserve Bank of New York Staff Reports, 313.

Nautz, D., And C. J. Offermanns (2007): "The Dynamic Relationship between the Euro Overnight Rate, the ECB's Policy Rate and the Term Spread," International Journal of Finance and Economics, 12(3), 287-300.

Nautz, D., And J. Scheithauer (2008): "Monetary Policy Implementation and Overnight Rate Persistence," Goethe University Frankfurt Discussion Paper.

O'Brien, Y.-Y. C. (2007): "Reserve Requirement Systems in OECD Countries," Finance and Economics Discussion Series 2007-054, Federal Reserve Board.

Poole, W., and R. H. Rasche (2003): "The Impact of Changes in FOMC Disclosure Practices on the Transparency of Monetary Policy: Are Markets and the FOMC Better "Synched"?," Federal Reserve Bank of St. Louis Review, 85(1), 1-9.

Prati, A., L. Bartolini, and G. Bertola (2003): "The Overnight Interbank Market: Evidence from the G-7 and the Euro Zone," Journal of Banking and Finance, 27, 20452083.

Pérez Quirós, G., And H. Rodríguez MendizÁbal (2006): "The Daily Market for Funds in Europe: What Has Changed with the EMU?," Journal of Money, Credit and Banking, 38(1), 91-118.

Rasche, R. H., and D. L. Thornton (2002): "The FOMC's Balance-of-Risks Statement and Market Expectations of Policy Actions," Federal Reserve Bank of St. Louis Review, $84(5), 37-50$.

SARno, L., And D. L. Thornton (2003): "The Dynamic Relationship between the Federal Funds Rate and the Treasury Bill Rate: An Empirical Investigation," Journal of Banking and Finance, 27, 1079-1110.

Thornton, D. L. (2006): "When Did the FOMC Begin Targeting the Federal Funds Rate? What the Verbatim Transcripts Tell Us," Journal of Money, Credit and Banking, 38(8), 2039-2071.

Thornton, D. L., And D. C. Wheelock (2000): "A History of the Asymmetric Policy Directive," Federal Reserve Bank of St. Louis Review, 82(5), 1-16.

VanHoose, D. D., And D. B. Humphrey (2001): "Sweep Accounts, Reserve Management and Interest Rate Volatility," Journal of Economics and Business, 53, 387-404. 
Woodford, M. (2000): "Monetary Policy in a World without Money," International Finance, 3(2), 229-60.

Wrase, J. M. (1998): "Is the Fed Being Swept Out of (Monetary) Control?," Business Review, Federal Reserve Bank of Philadelphia, November/December 1998.

\section{A Appendix}

\section{A.1 Figures}

Figure 5: Total deposits

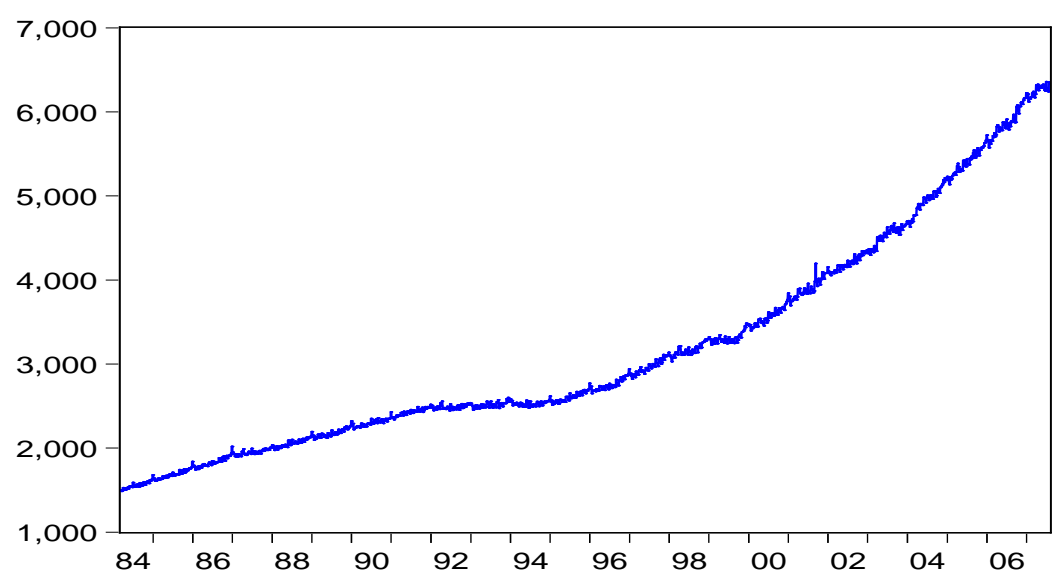

Notes: Total deposits in bn USD, non-seasonally adjusted. Adjusted for breaks caused by reclassifications of assets and liabilities.

Figure 6: Required reserves, total reserves, and required reserve balances

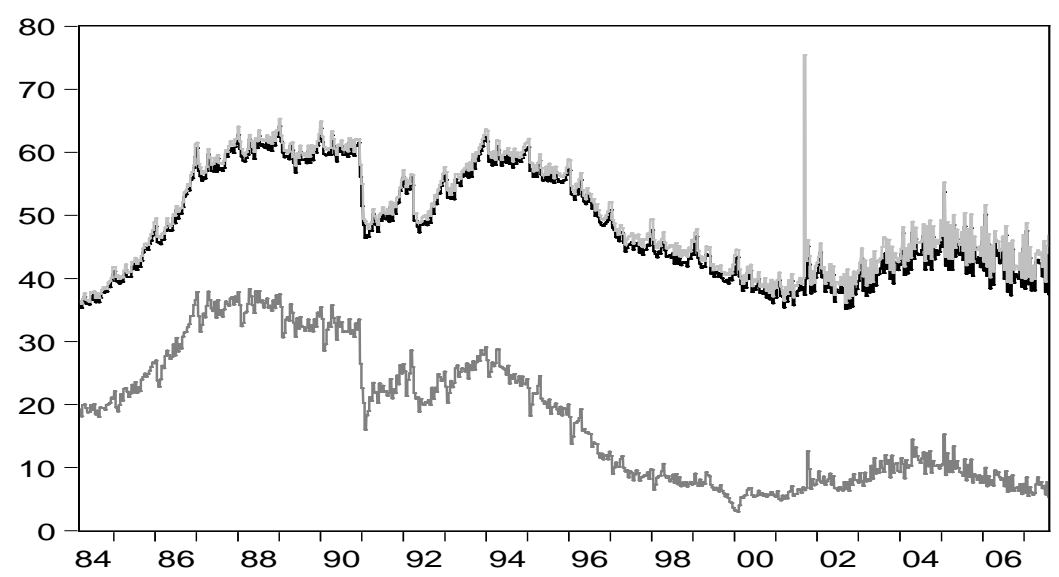

Notes: Reserve requirements (black line), total reserves (light-grey line) and required reserve balances at the Fed (dark-grey line), in bn USD. Series are non-seasonally adjusted and not adjusted for breaks due to institutional changes in the reserve requirement framework. 


\section{A.2 Alternative measures for required reserves}

Following Carpenter and Demiralp (2008), we furthermore checked the robustness of the estimation results by employing (1) total reserves and (2) required reserve balances as alternative measures for required reserves. Banks can use required reserve balances or optionally vault cash to meet their reserve requirements. As Figure 6 exemplifies, required reserve balances develop similarly to required reserves. Moreover, total reserves are relatively close to required reserves, except for days around September 11, 2001. The alternative estimation results, which are available upon request, confirm the robustness of our results.

\section{A.3 Stationarity tests}

Table 5: Unit root tests

\begin{tabular}{llllll}
\hline \hline Variable & ADF-t-statistic & Variable & ADF-t-statistic & Variable & ADF-t-statistic \\
\hline$i$ & -1.831 & $\Delta i$ & $-24.770^{* *}$ & $\left(i-i^{*}\right)$ & $-12.002^{* *}$ \\
$i 3$ & -2.013 & $\Delta i 3$ & $-46.932^{* *}$ & $(i 3-i)$ & $-5.342^{* *}$ \\
\hline \hline
\end{tabular}

Notes: ADF-t-statistics result from test equations with a constant and automatic lag length selection according to Schwartz information criterion. Critical values at 5\% (1\%) are -2.862 $(-3.431){ }^{* *}$ denotes the rejection of a unit root at a significance level of $1 \%$.

\section{A.4 Federal funds rate behavior and the martingale hypothesis}

In accordance with Hamilton (1996), Table 6 exhibits significant calendar effects and a predictable pattern in the federal funds rate within a maintenance period. Contradicting the martingale hypothesis, our estimates show a lower federal funds rate on Fridays and a higher rate on the second Monday of a period. Hamilton (1996) finds this effect on both Mondays. The tightness of the money market on Settlement Wednesday is confirmed up to July 1998. During this period, the Settlement Wednesday coefficient indicates that the federal funds rate increases by 16 percentage points from the previous day in addition to the regime-dependent base effect. Daily fluctuations normally deviate from the base effect by less than 5 percentage points. Apparently, the behavior of the federal funds rate on Settlement Wednesday has changed due to the additional liquidity injections by the Fed since August 1998. Since then, the federal funds rate tends to decline on the last day of the period by approximately 2 percentage points relative to the base effect. 
Table 6: Detailed estimation results, mean equation

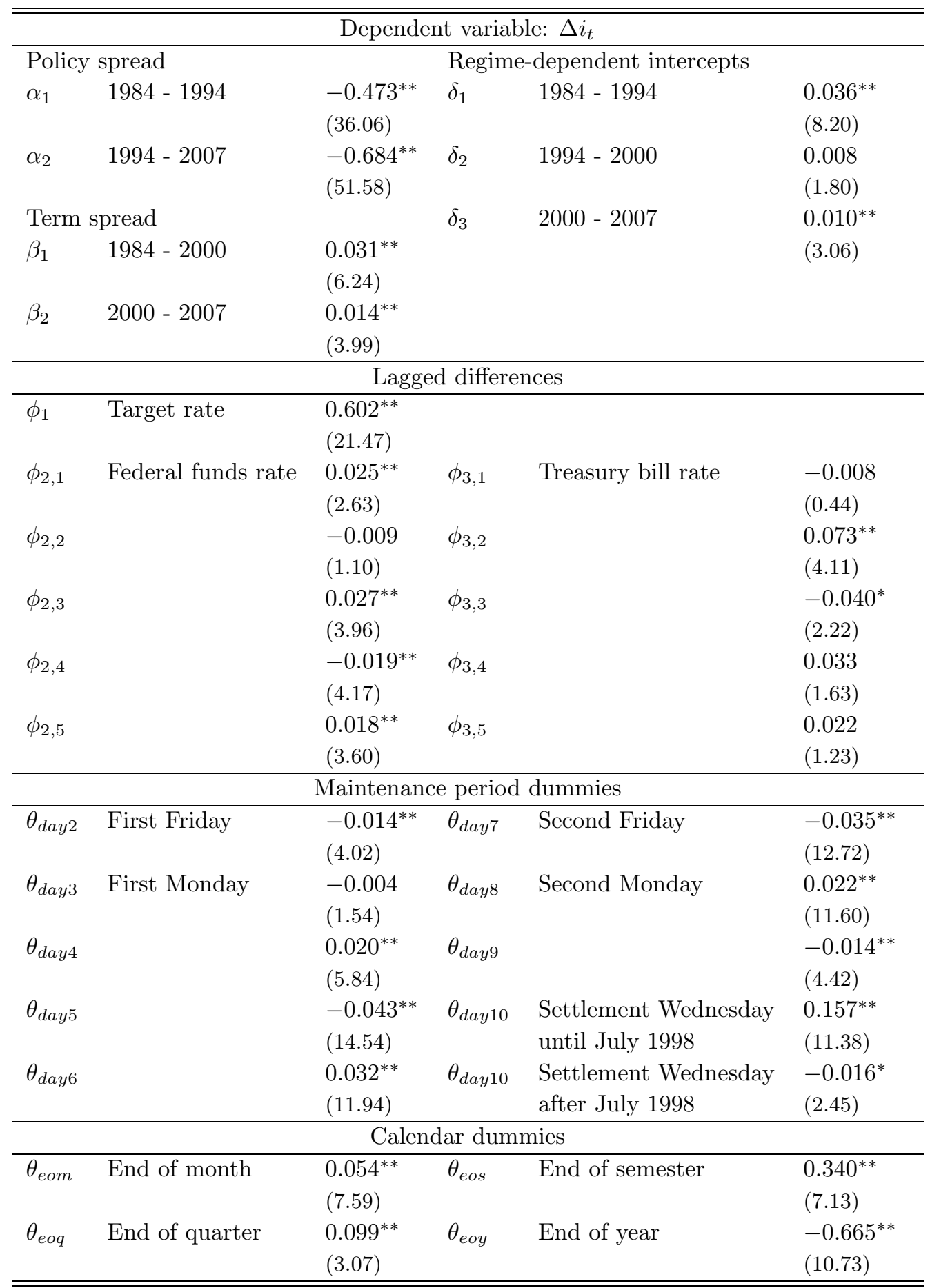

Notes: Estimation on basis of daily data. HAC consistent, absolute t-values in parenthesis. ${ }^{* *} /{ }^{*}$ denotes significance at the 1\%-/5\%-level. Estimation refers to Equations (1) and (2). 
Table 7: Detailed estimation results, volatility equation

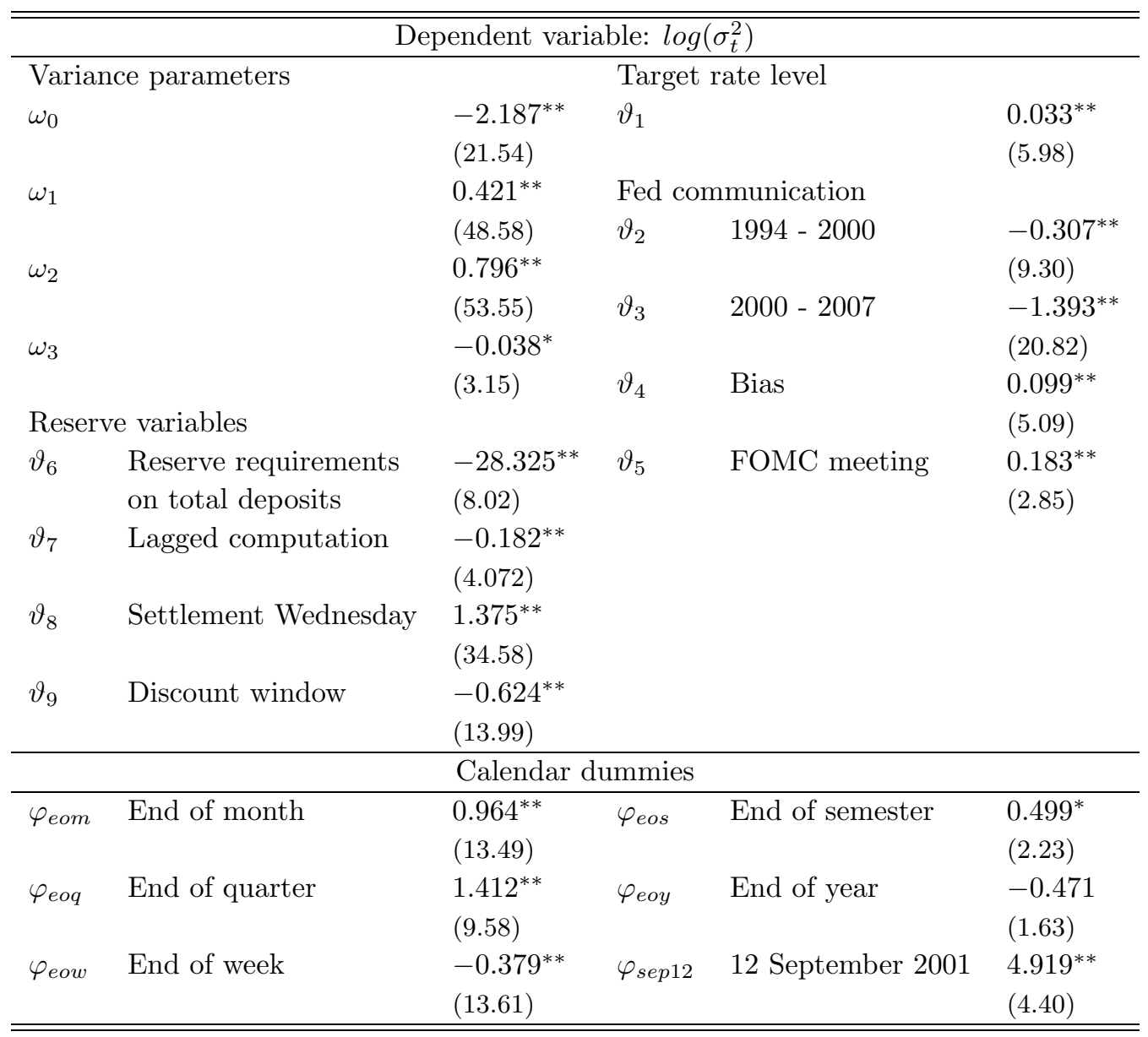

Notes: Estimation on basis of daily data. HAC consistent, absolute t-values in parenthesis. **/* denotes significance at the $1 \%$-/5\%-level. $D^{B I A S}$ indicates the effect relative to a neutral assessment. Estimation refers to Equations (1) and (2). 
Table 8: Definition of variables

\begin{tabular}{|c|c|c|}
\hline \multicolumn{2}{|l|}{ Variable } & Definition \\
\hline \multicolumn{2}{|l|}{$i$} & Effective federal funds rate \\
\hline \multicolumn{2}{|l|}{$i^{*}$} & Federal funds rate target \\
\hline \multicolumn{2}{|l|}{$i 3$} & 3-month Treasury bill rate \\
\hline \multicolumn{2}{|l|}{$r r$} & Required reserves divided by total deposits, see equation (3) \\
\hline \multicolumn{3}{|c|}{ Dummy variables } \\
\hline \multirow[t]{2}{*}{$D^{I}$} & 1 & Implicit federal funds rate targeting, 1 Mar 1984 to 31 Jan 1994 \\
\hline & 0 & 1 Feb 1994 to 8 Aug 2007 \\
\hline \multirow[t]{2}{*}{$D^{I I}$} & 1 & Immediate release of interest rate decisions, 1 Feb 1994 to 18 Jan 2000 \\
\hline & 0 & 1 Mar 1984 to 31 Jan 1994 and 19 Jan 2000 to 8 Aug 2007 \\
\hline \multirow[t]{2}{*}{$D^{I I I}$} & 1 & Balance of risks assessment, 19 Jan 2000 to 8 Aug 2007 \\
\hline & 0 & 1 Mar 1984 to 18 Jan 2000 \\
\hline \multirow[t]{2}{*}{$D^{B I A S}$} & 1 & Bias (asymmetric assessment) \\
\hline & 0 & Neutral assessment \\
\hline \multirow[t]{2}{*}{$D^{F O M C}$} & 1 & Federal Open Market Committee (FOMC) meeting days \\
\hline & 0 & Intermeeting periods \\
\hline \multirow[t]{2}{*}{$D^{L R R}$} & 1 & Lagged reserve computation, 1 Aug 1998 to 8 Aug 2007 \\
\hline & 0 & Contemporaneous reserve computation, 1 Mar 1984 to 31 Jul 1998 \\
\hline \multirow[t]{2}{*}{$D^{D W}$} & 1 & New discount window facility, 9 Jan 2003 to 8 Aug 2007 \\
\hline & 0 & 1 Mar 1984 to 8 Jan 2003 \\
\hline \multirow[t]{2}{*}{$D^{E O P}$} & 1 & End of maintenance period (Settlement Wednesday) \\
\hline & 0 & Maintenance period days 1 to 9 \\
\hline \multicolumn{2}{|l|}{$X_{1}, X_{2}$} & Calendar effects and maintenance period days \\
\hline$D^{D A Y(j)}$ & 1 & Day $j$ of a maintenance period \\
\hline$D^{E O Y}$ & 1 & End of year \\
\hline$D^{E O S}$ & 1 & End of semester \\
\hline$D^{E O Q}$ & 1 & End of quarter \\
\hline$D^{E O M}$ & 1 & End of month \\
\hline$D^{E O W}$ & 1 & End of week \\
\hline$D^{S e p 12}$ & 1 & Day after 11 September 2001 \\
\hline
\end{tabular}

Notes: Original data frequency: Daily (interest rates), biweekly averages ending on Wednesday (reserve requirements), weekly averages ending on Wednesday (deposits). Data sources: EcoWin/Fed (interest rates) and the Fed (reserves and deposits). $D^{B I A S}$ indicates an asymmetric assessment in the FOMC policy directive until January 2000 (data from Thornton and Wheelock (2000)) and in the balance of risks assessment afterwards (own calculations based on FOMC statements). The corresponding values are assigned on FOMC decision days and remain valid during the consecutive intermeeting period. 